O矢吹今日子, 小寺一興（帝京大耳息科）

1. 目的

難聴者にたいする補聴器の器種の選択では, 会話音を快適レベル（MC L ）で閉くため に十分な利得をうるととができ，不快レベル（UCL）に達しないよう最大出力音正を調 節できる器種を選択することが望ましい。したがって，MCLとUCL の测定值は，補聴 器適合の基礎的データとして有用である。とてろで, 従来の MCLとUCL の研究は純音 を川いた報告が多く，その值を会話恥取を目的として実際に応川するにはいくつかの不明 な点がある。すなわち, 純音にたいする MCL PUCLと会話音のそれに差があるのかど うか, 純音と会話音を対比する場合に, 会話音の值としては長時間実効值とピーク值のい ずれを採用したらよいのかは不明である。また, 测定機器についても不明な点が残されて いる。一般にスピーカやヘッドホンが川いられているが，高度感音難聴者では補聴器を川 いた测定も考えられる。ところが，てれら测定機器を変化させた場令，その值に楜いがあ

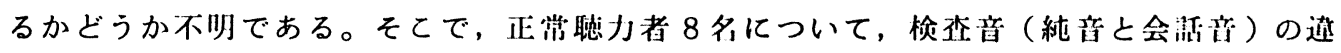

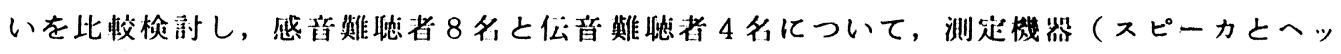
ドホン及び補恥器）の違いを比較検澎した。

2. 刘象ट日的

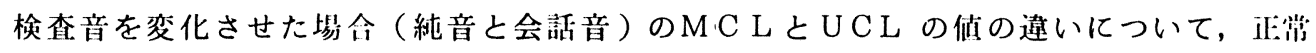
聴力者 8 多を対象として比較検討した。会話音による测定方法は，スピーカ前 $1 \mathrm{~m}$ の位睍 に被検者を着店させて, スピーカから検查音を提示し検査を行った。音源には, 女性の朗 読と男性の朗読を録音した 2 種類のテープを川いた。純音の場令は, 防音室队の被検者に ヘッドホンを通して娭査音を提示した。検査音は, $125 \mathrm{~Hz}, 250 \mathrm{~Hz}, 500 \mathrm{~Hz}, 1000 \mathrm{~Hz}$, $2000 \mathrm{~Hz}, 4000 \mathrm{~Hz}$ の 6 周波数を测定に川いた。純音のUCL の测定は，ブースタをオージ オメータに接絟して行った。

検杢機器を変化させた塯合（スピーカと補聴器, ヘッドホンと補聴器）のMCL とUC Lの值の違いについて, 感音難聴者 8 名と伀音難恥者 4 名を刘象として比較検郝した。ま ず,スピーカと補聴器の違いについて比較した。刘象は, 感音難恥者 8 多とした。音源は,

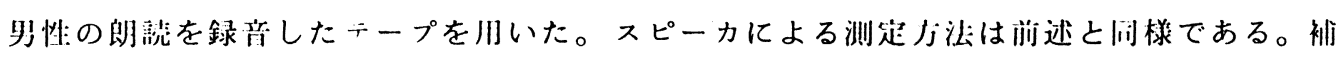

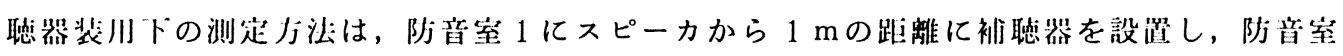
2 で被榆者にイヤホンを通して検査音を提示し検査を行った。さらに、ヘッドホンと補恥 器の趡いを，伀音難恥者 4 多を対象として比較した。へッドホンでは, 純音の $500 \mathrm{H}$ $1000 \mathrm{~Hz}$ を検查音とし, 補聴器からは会諨音を検査音とした。いずれも $5 \mathrm{~dB}$ ステップで音 任を」:显させて検查音を捉示した。

UCL と MCLのレベルの测定は, 白覚闒估，MCLの下限，MCL，MCLの上限， U C L の下限，UCL の 6 段階の答えを㹮いたカードをすわたし，各音迆ごとに感じたカ 一ドを提示させた。そ机ぞ各2 回ずつ测定を行い，解析には，2回日の值を川いた。

3. 絬果

図 1 に，検烃音を変化させた测定結果を示した。純音の周波数 $250 \mathrm{H}, 500 \mathrm{~Hz}, 1000 \mathrm{~Hz}$ Audiology Japan Vol.31, No. 5, 1988 


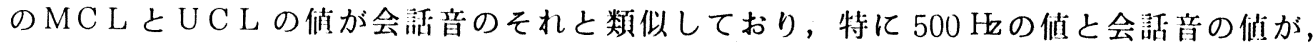
もっとも一致していた。また，会活音を音源とした埸合，罗の装と，女の声で差を認めな かった。四 2 と図 3 に, 测定機器を変化させた違いを示した。図 2 に, 感音難聴者を刘象 としてスピーカと補聴器の違いを比較した测定絬果をしめした。スピーカと補聴器で, そ の值に差を認めなかった。図 3 に, 伝音難聴者を対象として補聴器とへッドホンの違いを 比較した测定絬果を示した。補聴器の U C L の测定值は, ヘッドホンに比へ, 約 5 〜 10dB 低い傎を示した。

\section{4. 考察}

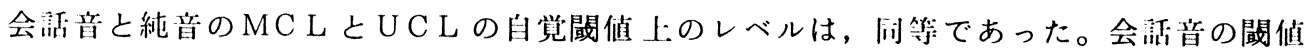
は, 会話音のピーク值に対応していると考えられるので, 会話音のMCLとUCLはピー ク值に刘応している。また，純音による测定值を会話音に適用するには， $500 \mathrm{~Hz}, 1000 \mathrm{~Hz}$ の值を川いるとよい。

测定機器を変化させた埸合, 感音難恥者を刘象としたスピーカと補聴器の比較では, M C L とUCL の值に差を認めなかった。一方，伀音難聴者を対象としたヘッドホンから与 えた純音と補聴器から与えた会㴗音の比較では, 後者の U C L は 5〜 10dB 低かった。この 原因は，䘞恥器をとうした会活音の歪を不快と感じたものと考えられた。不快レべルを考 える塌令に，機器の変化がレベルの変化を起しうるととに考虑すべきである。

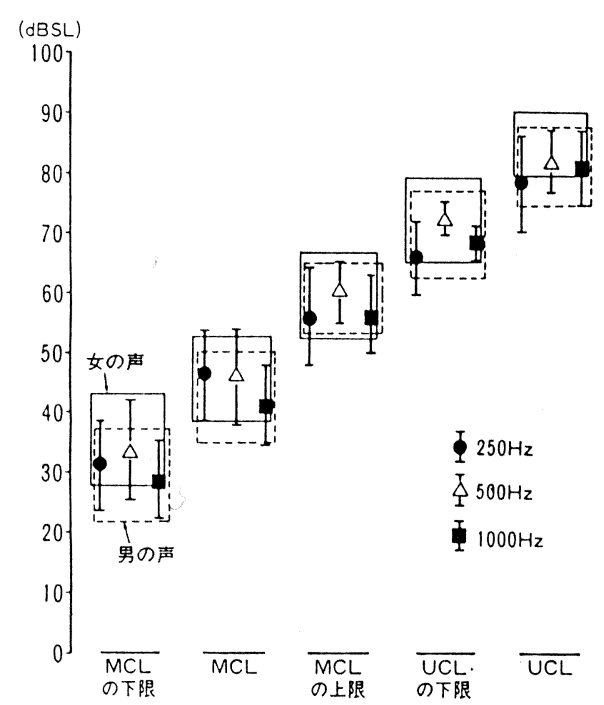

図1，純音と会話音

細は、それぞれのレベルにたいする 感觉レベル（S L) を示す。の盺は純音 の $250 \mathrm{~Hz} 、 \triangle$ 甲は $500 \mathrm{~Hz} 、$ 口は1000Hzの值 を示し、実線で用んだ挅は女性の㽗読、 点線で用んだ挅は男性の期読の值を示す。
(dBSL)

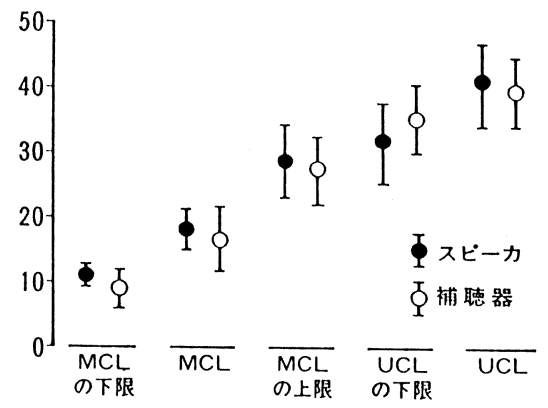

図2.スピーカと補聴器

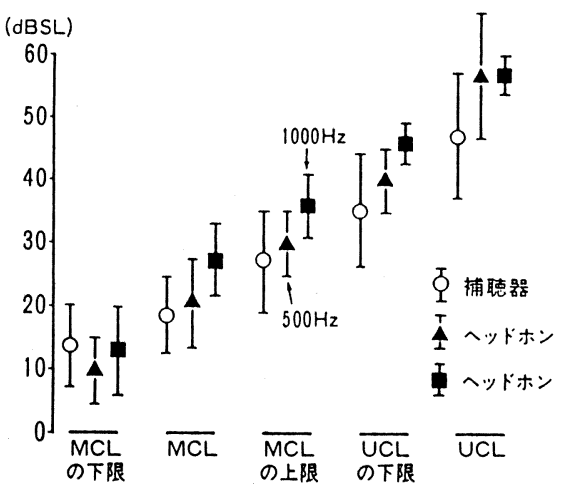

図3.ヘッドホンと補聴器

の妇はスピーカ、・用曰印はヘッドホンの

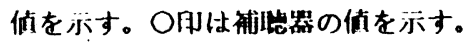

